\title{
Inhibition of Palmityl Carnitine Oxidation in Rat Liver Mitochondria by Tert-Butyl Hydroperoxide
}

\author{
Z. ČERVINKOVÁ ${ }^{1}$, H. RAUCHOVÁ ${ }^{2}$, P. KŘIVÁKOVÁ ${ }^{1}$, Z. DRAHOTA ${ }^{1,3}$ \\ ${ }^{1}$ Department of Physiology, Faculty of Medicine in Hradec Králové, Charles University in Prague, \\ ${ }^{2}$ Institute of Physiology, Academy of Sciences of the Czech Republic, Center for Cardiovascular \\ Research, Prague, ${ }^{3}$ Institute of Physiology, Academy of Sciences of the Czech Republic, Center for \\ Applied Genomics, Prague, Czech Republic
}

Received January 22, 2007

Accepted February 12, 2007

On-line April 25, 2007

\section{Summary}

Mitochondria as an energy generating cell device are very sensitive to oxidative damage. Our previous findings obtained in hepatocytes demonstrated that Complex I of the respiratory chain is more sensitive to oxidative damage than other respiratory chain complexes. We present additional data on isolated mitochondria showing that palmityl carnitine oxidation is strongly depressed at a low $(200 \mu \mathrm{M})$ tert-butyl hydroperoxide (tBHP) concentration, while oxidation of the flavoproteindependent substrate - succinate is not affected and neither is ATP synthesis inhibited by $\mathrm{tBHP}$. In the presence of $\mathrm{tBHP}$, the respiratory control index for palmityl carnitine oxidation is strongly depressed, but when succinate is oxidized the respiratory control index remains unaffected. Our findings thus indicate that flavoprotein-dependent substrates could be an important nutritional factor for the regeneration process in the necrotic liver damaged by oxidative stress.

\section{Key words}

Liver mitochondria - Palmityl carnitine oxidation - tert-butyl hydroperoxide

\section{Corresponding author}

Zuzana Červinková, Department of Physiology, Charles University in Prague, Faculty of Medicine in Hradec Králové, Šimkova 870, 50038 Hradec Králové, Czech Republic. E-mail: wolff@lfhk.cuni.cz
Liver cells represent an important factor in the traffic of lipids as a nutritional energy source for animal organisms (Havel 1987). Some lipids, namely short- and medium-chain fatty acids entering the liver through the portal vein, are oxidized directly in hepatocytes by mitochondria to cover their energy demands.

It is now commonly accepted that mitochondria are not only an important generator of reactive oxygen species (Boveris and Chance 1973, Chance et al. 1979), but also an important target of their action (Turrens and Boveris 1980, Kovaltowski and Vercesi 1999, NultonPresson and Szweda 2001, Turrens 2003). Liver tissue is especially sensitive to various toxic agents that induce processes in which reactive oxygen species play an important role (Shu et al. 1997, Knight et al. 2003).

There are many studies describing peroxidative damage of liver mitochondria (Kennedy et al. 1992, Kowaltowski and Vercesi 1999, Nulton-Persson and Szweda 2001, Lin et al. 2002) and hepatocytes (Masaki et al. 1989, Nieminen et al. 1997, Kmoníčková et al. 2001). However, there are not sufficient comparative data to evaluate the sensitivity of various mitochondrial dehydrogenases to peroxidative damage.

This is why in our previous experiments on isolated hepatocytes we studied the peroxidative damage of mitochondrial enzymes induced by tert-butyl hydroperoxide (tBHP). In these studies, we used tBHP as the prooxidant because, unlike hydrogen peroxide, it is not degraded by catalase (Chance et al. 1979) and 
consequently its peroxidative effect can be studied over a longer period of incubation. We found that oxidation of NADH-dependent substrates is extremely sensitive to peroxidative damage and that oxidation of flavoproteindependent substrates is partially reduced (Drahota et al. 2005, Křiváková et al. 2007).

It has not been fully elucidated to what extent the toxic effects of prooxidants are due to the direct action on mitochondrial enzymes and to what extent secondary radical metabolites are formed in the cytosol (Kennedy et al. 1992) and could thus also be involved in peroxidative damage when isolated hepatocytes are used. Based upon our previous experiments on hepatocytes, we measured in the present study isolated mitochondria and tested to what extent fatty acid oxidation and succinate oxidation are affected by tBHP. In order to obtain additional data, we tested the effect of tBHP on palmityl carnitine and succinate oxidation on isolated liver mitochondria under the same experimental conditions. We compared the effect of tBHP on palmityl carnitine and succinate oxidation, because oxidation of palmityl carnitine involves two mitochondrial dehydogenases, a NADH- and a flavoprotein-dependent one, whereas succinate is oxidized only by the flavoprotein-dependent dehydrogenase.

Liver mitochondria were isolated from male Wistar rats (220-230 g) by differential centrifugation as described previously (Ješina et al. 2004). Oxygen uptake was measured with the High Resolution Oxygraph2K (Oroboros, Austria). Measurements were taken at $30^{\circ} \mathrm{C}$ in $2 \mathrm{ml}$ of incubation medium containing $100 \mathrm{mM} \mathrm{KCl}$, $10 \mathrm{mM}$ Tris $\mathrm{HCl}, 4 \mathrm{mM} \mathrm{K}$-phosphate, $3 \mathrm{mM} \mathrm{MgCl}_{2}$, $1 \mathrm{mM}$ EDTA, $0.5 \mathrm{mg} / \mathrm{ml}$ fatty acid-free bovine serum albumin, $\mathrm{pH}$ 7.4. The rate of oxygen uptake was expressed as $\mathrm{pmol} / \mathrm{s} / \mathrm{mg}$ protein. Oxygen uptake curves are presented as the first negative derivation of the oxygen tension changes.

Figure 1 demonstrates the experimental conditions used for the evaluation of tBHP effect on the oxidation of palmityl carnitine and succinate performed by rat liver mitochondria. In contrast to other respiratory substrates, which are used in high (millimolar) concentrations, palmityl carnitine must be tested at micromolar concentrations, because at higher concentrations it exerts a detergent-like effect on mitochondrial membranes. We used $5 \mu \mathrm{M}$ palmityl carnitine and $2.5 \mathrm{mM}$ malate as a sparker. After the addition of ADP, the oxygen uptake was highly activated (fivefold, Fig. 1A, Table 1), indicating that mitochondria are well coupled and that this concentration of the palmityl carnitine had no detergent-like effect. When palmityl carnitine was oxidized, the respiratory rate decreased and another portion of palmityl carnitine induced a similar response in oxygen uptake (Fig. 1A). The addition of rotenone, an inhibitor of Complex I, completely inhibited palmityl carnitine oxidation (not shown). The addition of succinate after palmityl carnitine again increased the rate of oxygen uptake to values about $30-50 \%$ higher than those obtained with palmityl carnitine and malate (Fig. 1A, Table 1). When tBHP was added after palmityl carnitine was oxidized, then subsequent addition of palmityl carnitine induced a much smaller increase in the respiratory rate (Fig. 1B). However, subsequent addition of succinate demonstrated that the rate of succinate oxidation was not depressed by tBHP (Fig. 1B, Table 1). The same results were obtained when the effect of tBHP on the oxidation of succinate was tested in the absence of palmityl carnitine and malate (Fig. 1C, D, Table 1).

Table 1. Inhibition of palmityl carnitine and succinate oxidation by tBHP.

\begin{tabular}{ll}
\hline & $\begin{array}{l}\text { pmol oxygen/s/mg } \\
\text { protein }\end{array}$ \\
\hline $\begin{array}{l}\text { Palmityl carnitine } \\
+ \text { malate }\end{array}$ & $117.0 \pm 14.0$ \\
$\begin{array}{l}\text { Palmityl carnitine } \\
+ \text { malate }+A D P\end{array}$ & $601.5 \pm 27.6$ \\
$\begin{array}{l}\text { Palmityl carnitine } \\
+ \text { malate }+ \text { ADP }+ \text { tBHP }\end{array}$ & $245.7 \pm 27.4^{*}$ \\
$\begin{array}{l}\text { Succinate } \\
+ \text { ADP }\end{array}$ & $907.6 \pm 53.0$ \\
$\begin{array}{l}\text { Succinate } \\
+ \text { ADP }+t B H P\end{array}$ & $883.9 \pm 29.9$ \\
\hline
\end{tabular}

Mitochondria were incubated as described in the legend to Fig. 1. The palmityl carnitine used was $5 \mu \mathrm{M}$, malate $2.5 \mathrm{mM}$, ADP 1.5 $\mathrm{mM}$, succinate $10 \mathrm{mM}$ and tert-butyl hydroperoxide $200 \mu \mathrm{M}$. The data presented depict the average \pm SEM from six liver mitochondrial preparations isolated from six adult male rats. Significant effect of tBHP $(p<0.001)$.

It is evident from our data that fatty acid oxidation is more sensitive than the oxidation of succinate to peroxidative damage (Fig. 1, Table 1). We may also conclude that under conditions, when fatty acid oxidation is highly depressed by tBHP (Fig. 1C, D), the 

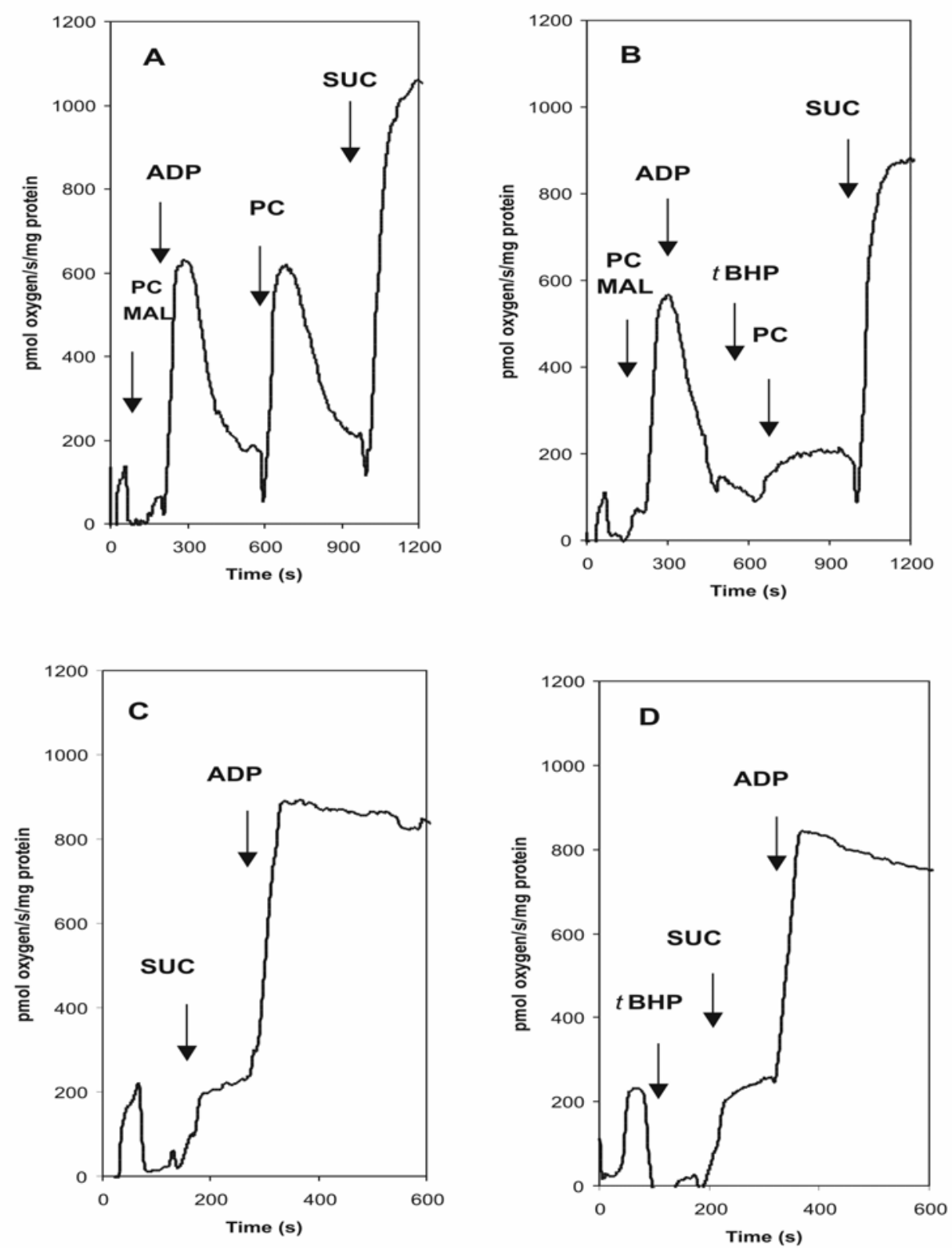

Fig. 1. Respiration of rat liver mitochondria in the presence of palmityl carnitine and succinate: Mitochondria $(0.2 \mathrm{mg}$ protein $/ \mathrm{ml})$ were incubated in a $\mathrm{KCl}$ medium with $0.5 \mathrm{mg}$ of bovine serum albumine. Where indicated, $2.5 \mathrm{mM}$ malate (MAL), $5 \mu \mathrm{M}$ palmityl carnitine (PC), $1.5 \mathrm{mM} \mathrm{ADP}, 10 \mathrm{mM}$ succinate (SUC) and $200 \mu \mathrm{M}$ t-butyl hydroperoxide (tBHP) were added. The respiratory control index (RCI) in part A was 5.2 and 5.0 ; in B 4.8 and 1.8; in C 4.3; and in part D, 3.9.

ATP synthase is active, because the respiratory rate induced by ADP is not affected (Table 1). Our data thus confirm our previous results obtained on isolated hepatocytes (Drahota et al. 2005, Křiváková et al. 2007), demonstrating that Complex I is the most sensitive part of the mitochondrial respiratory chain to peroxidative damage. Experiments on isolated mitochondria further indicate that the inhibition of Complex $I$ is not necessarily connected with the collapse of membrane potential if flavoprotein-dependent substrates are accessible. These conclusions are also supported by our previous data on isolated hepatocytes (Lábajová et al.
2006), demonstrating that the dissipation of the mitochondrial membrane potential by tBHP, when pyruvate and malate are used as respiratory substrates, can be fully recovered by succinate.

Our data showing that fatty acid oxidation is highly sensitive to oxidative damage could be an important information for the treatment of necrotic liver tissue because most hepatotoxic agents are known to be inducers of reactive oxygen species (Knight et al. 2003, Sundari et al. 1997). For the activation of the regeneration process, therefore, flavoprotein-dependent substrates could play an important role. 


\section{Conflict of Interest}

There is no conflict of interest.

\section{Acknowledgement}

This work was supported by grants MSM 0021620820 , GAČR 303/03/H065, GAČR 305/04/0500, and $1 \mathrm{M} 6837805003$.

\section{References}

BOVERIS A, CHANCE B: The mitochondrial generation of hydrogen peroxide. Biochem J 134: 707-716, 1973.

CHANCE B, SIES H, BOVERIS A: Hydroperoxide metabolism in mammalian organs. Physiol Rev 59: 527-605, 1979.

DRAHOTA Z, KŘIVÁKOVÁ P, ČERVINKOVÁ Z, KMONÍČKOVÁ E, LOTKOVÁ H, KUČERA O, HOUŠTĚK J: tert-butyl hydroperoxide selectively inhibits respiratory-chain enzymes in isolated rat hepatocytes. Physiol Res 54: 67-72, 2005.

HAVEL RJ: Lipid transport function of lipoproteins in blood plasma. Am J Physiol 253: E1-E5, 1987.

JEŠINA J, KHOLOVÁ D, BOLEHOVSKÁ R, ČERVINKOVÁ Z, DRAHOTA Z, HOUŠTĚK J: Glycerophosphatedependent hydrogen peroxide production by rat liver mitochondria. Physiol Res 53: 305-310, 2004.

KENNEDY CH, CHURCH DF, WINSTON GW, PRYOR WA: Tert-butyl hydropreoxide-induced radical production in rat liver mitochondria. Free Radic Biol Med 12: 381-387, 1992.

KMONÍČKOVÁ E, DRAHOTA Z, KAMENÍKOVÁ L, ČERVINKOVÁ, Z, MAŠEK K, FARGHALI H: Modulatory effect of cyclosporin A on tert-butyl hydroperoxide-induced oxidative damage in hepatocytes. Immunopharmacol Immunotoxicol 23: 43-54, 2001.

KNIGHT TR, FARISS MW, FARHOOD A, JAESCHKE H: Role of lipid peroxidation as a mechanism of liver injury after acetaminophen overdose in mice. Toxicol Sci 76: 229-236, 2003.

KŘIVÁKOVÁ P, LÁBAJOVÁ A, ČERVINKOVÁ Z, DRAHOTA Z: Inhibitory effect of $t$-butyl hydroperoxide on mitochondrial oxidative phosphorylation in isolated hepatocytes. Physiol Res 56: 137-140, 2007.

KOVALTOWSKI AJ, VERCESI AE: Mitochondial damage induced by conditions of oxidative stress. Free Radic Biol Med 26: 463-471, 1999.

LIN K-L, HUGHES G, MURATOWSKA A, BLAIKIE FH, BROOKES PS, DARLEY-USMAR V, SMITH RAJ, MURPHY MP: Specific modification of mitochondrial protein thiols in response to oxidative stress. $J$ Biol Chem 277: 17048-17056, 2002.

LÁBAJOVÁ A, KOFRÁNEK J, KŘIVÁKOVÁ P, ČERVINKOVÁ Z, DRAHOTA Z: TTP ${ }^{+}$-selective electrode as a tool for evaluation of mitochondrial membrane permeability pore function in isolated rat hepatocytes. Gen Physiol Biophys 25: 325-331, 2006.

MASAKI N, KYLE ME, SERRONI A, FARBER JL: Mitochondrial damage as a mechanism of cell injury in the killing of cultured hepatocytes by tert-butyl hydroperoxide. Arch Biochem Biophys 270: 672-680, 1989.

NIEMINEN A-L, BYRNE AM, HERMAN B, LEMASTERS JJ: Mitochondrial permeability transition in hepatocytes induced by t-BuOOH: NAD(P)H and reactive oxygen species. Am J Physiol 272: C1286-C1294, 1997.

NULTON-PRESSON AC, SZWEDA LI: Modulation of mitochondrial function by hydrogen peroxide. $J$ Biol Chem 276: 23357-23361, 2001.

SHU Z, JUNG M, BEGER HG, MARZINZIG M, HAN F, BUTZER U, BRUCKNER UB, NUSSLER AK: pHdependent changes of nitric oxide, peroxynitrite, and reactive oxygen species in hepatocellular damage. $A m J$ Physiol 273: G1118-G1126, 1997.

SUNDARI PN, WILFRED G, RAMAKRISHNA B: Does oxidative protein damage play a role in the pathogenesis of carbon tetrachloride-induced liver injury in rat, Biochim Biophys Acta 1362: 169-172, 1997.

TURRENS JF: Mitochondrial formation of reactive oxygen species. J Physiol Lond 552: 335-344, 2003.

TURRENS JF, BOVERIS A: Generation of superoxide anion by the NADH dehydrogenase of bovine heart mitochondria. Biochem J 191: 421-427, 1980. 